\title{
Pro239Ser: A Novel Recessive Mutation of the Pit-1 Gene in Seven Middle Eastern Children with Growth Hormone, Prolactin, and Thyrotropin Deficiency*
}

\author{
FLAVIA PERNASETTI $\dagger$, ROBERT D. G. MILNER $\ddagger$ ABDULLAH A. Z. AL ASHWAL, \\ FRANCIS de ZEGHER, VIVIANA M. CHAVEZ\$, MARC MULLER, AND \\ JOSEPH A. MARTIAL
}

\begin{abstract}
Laboratory of Molecular Biology and Genetic Engineering (F.P., V.M.C., M.M., J.A.M.), University of Liège, B-4000 Sart Tilman, Liège, Belgium; Department of Obstetrics, Gynecology and Pediatrics (R.D.G.M., F.d.Z.), University of Leuven, B-3000, Leuven, Belgium; Department of Pediatrics (A.A.Z.A.A.), King Faisal Specialist Hospital and Research Center, 11211 Riyadh, Kingdom of Saudi Arabia
\end{abstract}

\begin{abstract}
Pit-1, a member of the POU-homeo domain protein family, is one of the transcription factors responsible for anterior pituitary development and pituitary-specific gene expression. Here, we describe seven children with GH, PRL, and TSH deficiency from three, reportedly unrelated, Middle Eastern families, harboring a newly rec-
\end{abstract}

ognized Pro- $>$ Ser recessive mutation in codon 239 of the Pit-1 gene. The mutated residue is located at the beginning of the second $\alpha$-helix of the POU-homeodomain and is strictly conserved among all POU proteins. The Pro239Ser mutant binds DNA normally but is unable to stimulate transcription. (J Clin Endocrinol Metab 83: 2079-2083, 1998)
$\mathrm{P}$ t-1/GHF-1 is a pituitary-specific transcription factor required for pituitary development and for expression of several anterior pituitary hormones (1-3). Pit-1 transactivates expression of the genes coding for GH, PRL, and TSH- $\beta$ $(4-8)$, among others. In addition to its role in cell-specific expression, Pit-1 also plays an essential role in the development of somatotroph, lactotroph, and thyrotroph cells in the anterior pituitary. As a member of the POU family, Pit-1 contains a highly conserved bipartite DNA-binding domain consisting of the POU-homeodomain (60 amino acids), required for low-affinity DNA binding, and of the POU-specific domain (approximately 75 amino acids) responsible for the specificity of DNA binding and for possible interactions with other proteins (9). The major transactivating function of Pit-1 resides in the N-terminal region of the protein, which functions as an independent activation domain when connected to a heterologous DNA-binding domain $(1,10)$.

Abnormalities in the Pit-1 gene were first observed in Snell

Received September 23, 1997. Revision received March 11, 1998. Accepted March 18, 1998.

Address all correspondence and requests for reprints to: Joseph A. Martial, Laboratory of Molecular Biology and Genetic Engineering, University of Liège, B-4000 Sart Tilman, Liège, Belgium. E-mail: jmartial@ulg.ac.be.

* This work was supported, in part, by grants from the Services Fédéraux des Affaires Scientifiques, Techniques et Culturelles (PAI P3042 and PAI P3-044) and from the Fonds National de la Recherche Scientifique (FRSM 3.4537.93).

+ A fellow of the National Council for Scientific and Technological Development, CNPq, Brazil. Current affiliation: Department of Reproductive Medicine, University of California, La Jolla, San Diego, California 92093-0674.

$\ddagger$ Died, February 1996

§ Current affiliation: Institute of Human Genetics, University of Minnesota, Minneapolis, Minnesota 55455. and Jackson dwarf mice. Their consequence was a combined pituitary hormone deficiency (CPHD) with hypoplasia of the anterior pituitary and no production of GH, PRL, or TSH (11). A number of CPHD patients are known to have a point mutation in the Pit-1 coding sequence (12-20). Some of these mutations affect the DNA-binding capacity $(12,20)$ of the Pit-1 protein, others alter its transactivation properties (1315). From a comparison of their pedigrees, it seems that some mutations in the Pit-1 gene (Arg271Trp and Pro24Leu) lead to a dominant-negative phenotype (13, 15-19); others (Arg172stop, Glu250Stop, Ala158Pro, Arg143Gln), to a recessive phenotype $(14,15,20)$.

Here, we report the identification of a novel homozygous Pro239Ser mutation in the Pit-1 gene of seven Middle Eastern hypopituitary children from three reportedly unrelated families. In addition, we present the properties of the mutant Pit-1 protein, with respect to transactivation, DNA binding, and interaction with its wild-type counterpart.

\section{Materials and Methods}

DNA extraction, PCR amplification, and automated direct sequencing

For DNA extraction from blood spots $\left(5 \mathrm{~mm}^{2}\right)$ on filter paper, we used the ChelexR 100 chelating resin, as described by Walsh and co-workers (21). PCR was used to amplify the six Pit-1 exons independently, using six pairs of oligonucleotides corresponding to the intron/exon boundaries (15). Reactions were carried out as follows: approximately $100 \mathrm{ng}$ genomic DNA, 20 pmol of each primer, $200 \mu \mathrm{mol} / \mathrm{L}$ of each nucleotide, 1 U Dynazyme polymerase, and $1 \times$ Dynazyme reaction buffer were mixed in a final vol of $100 \mu \mathrm{L}$. Reactions were cycled 30 times for $1 \mathrm{~min}$ at $94 \mathrm{C}, 1 \mathrm{~min}$ at $55 \mathrm{C}$, and $1 \mathrm{~min}$ at $72 \mathrm{C}$. The amplified products were electrophoresed on $1.5 \%$ agarose gel and stained with ethidium bromide to evaluate their size, purity, and quantity. Sequencing was performed 
directly on the amplified fragments, thus allowing immediate evaluation of heterozygosity.

\section{Site-directed mutagenesis}

We used the CHAMELEON double-stranded, site-directed mutagenesis kit from Stratagene Cloning Systems (La Jolla, CA) to obtain the mutated Pit-1 complementary DNA (cDNA). A plasmid, containing nonmutated human Pit-1 cDNA cloned behind the RSV promoter (pRSVhPit-1) (22), was used as a template.

The oligonucleotide 5'CTCTTGAGAAGAAGATTTATTCTGTTCTCC3', containing the specific T-to-C substitution in codon 239, on the antisense strand, was employed. Mutated clones were tested by DNA sequencing and restriction analysis.

\section{In vitro transcription / translation reactions}

For in vitro transcription and translation, both the wild-type and the mutant Pit- 1 cDNA were inserted into the $\mathrm{XbaI}-\mathrm{XbaI}$ sites of plasmid pSVK3 from Pharmacia LKB Biotechnology (Uppsala, Sweden), which contains a T7 promoter. The in vitro reactions were carried out using the coupled transcription/translation system: $\operatorname{TnT}^{\mathrm{a}}$ Coupled Reticulocyte Lysate Systems (from Promega, Madison, WI) and [35S]-labeled methionine. Translation products were checked by electrophoresis on $5 \%$ polyacrylamide gels, and two major species ( 31 and $33 \mathrm{kDa}$ ) were observed, as expected (data not shown).

\section{Gel-retardation assays}

For the binding assays, we used the same amount of in vitro translated proteins, as judged by protein gel autoradiography (overnight exposure). The assays were performed in a mixture containing $2 \mu \mathrm{L}$ translated protein solution, $1 \mu \mathrm{g}$ poly dIdC, $7 \mathrm{mmol} / \mathrm{L}$ HEPES ( $\mathrm{pH}$ 7.9), $4 \%$ glycerol, $4 \%$ Ficoll, $100 \mathrm{mmol} / \mathrm{L} \mathrm{KCl}, 1 \mathrm{mmol} / \mathrm{L} \mathrm{MgCl} 2,0.1 \mathrm{mmol} / \mathrm{L}$ EDTA, $2 \mathrm{mmol} / \mathrm{L}$ dithiothreitol, and 10,000 cpm labeled hPRLP1 oligonucleotide (8), in a final vol of $20 \mu \mathrm{L}$. Two microliters of anti-Pit-1 antibodies or control serum was added when necessary. Binding was carried out for $30 \mathrm{~min}$ at $4 \mathrm{C}$ ( $1 \mathrm{~h}$ with antibodies), after which samples were loaded on a $5 \%$ polyacrylamide gel, in TBE $0.5 \mathrm{X}$, for electrophoresis.

\section{Production of anti-Pit-1 antibodies}

A fragment of human Pit-1 cDNA, containing the coding regions for the N-terminus and a small part of the POU-domain (amino acids 1-193), was cloned in the pT7 bacterial expression vector and expressed in the bacterial strain BL21 after addition of $100 \mathrm{mmol} / \mathrm{L}$ IPTG and incubation at $37 \mathrm{C}$ for $1 \mathrm{~h}$. The approximately $23-\mathrm{kDa}$ protein was subsequently purified for use as an antigen. The activity of the serum from injected rabbits was tested on Western blots (data not shown) with pituitaryderived cell extracts (GC, GH3), and the expected 31- to 33-kDa doublet bands corresponding to Pit-1 were obtained. We observed no extra bands corresponding to other POU family members, such as Oct-1, proving the high specificity of the antibodies against Pit-1. As expected, no bands appeared in the negative control performed with nonpituitary cell $(\mathrm{HeLa})$ extracts.

\section{Cotransfection assays}

Human HeLa cells were plated on $60-\mathrm{mm}$ plates at a density of $5 \times$ $10^{5}$ cells per plate and transfected with $5 \mu \mathrm{g}$ of reporter plasmid $\mathrm{p}(\mathrm{GH} 1) 6$ XTKCAT (23). The amount of effector plasmid was kept constant by addition of RSV- $\beta$ gal, where appropriate, as indicated in the figure legends. We used the calcium phosphate copreciptation method for transfection. Cells were harvested $48 \mathrm{~h}$ after transfection, and chloramphenicol-acetyl-transferase (CAT) assays were performed as previously described (23). The data shown are averages of at least three independent experiments, with error bars indicating the SEM.

\section{Oligonucleotides and enzymes}

The oligonucleotides used in this study were from Eurogentec (Seraing, Belgium) and the enzymes from Boehringer, Eurogentec, GibcoBRL, New England Biolabs, and Pharmacia.

\section{Results \\ Subjects and endocrine studies}

All described patients presented a clinical picture of congenital hypothyroidism and early growth failure and were referred to the King Faisal Specialist Hospital and Research Center. Studies were carried out with the informed consent of all parents.

The seven children were from three, reportedly independent families from the Al-Baha region in the Southwest of Saudi Arabia. In each case, the parents were second-degree relatives (see Fig. 1) and of normal stature for this community. The maternal height ranges from 149.5 to $159.2 \mathrm{~cm}$ and the paternal height, from 162.6 to $166.4 \mathrm{~cm}$.

All seven children were GH-, PRL-, and TSH-deficient. In all cases, serum GH concentration was less than $0.3 \mu \mathrm{g} / \mathrm{L}$, after a clonidine stimulation test or insulin tolerance test; basal PRL concentration in serum was $<3 \mu \mathrm{g} / \mathrm{L}$ in either hypothyroid $(n=2)$ or euthyroid $(n=5)$ conditions, and thyroid hormone levels were below the reference range for the age, with undetectable serum concentrations of TSH $(<0.1 \mathrm{mIU} / \mathrm{L})$. In each case, a so-called empty sella turcica was visualized by computed tomography scan.

All children were treated with $\mathrm{L}^{-\mathrm{T}_{4}}$ from early infancy. They also received a GH therapy, which started between the ages of 4 months and 3 yr plus 4 months. The height deficit, after adjustment for midparental height SD increased with advancing age, amounting to -2.9 SD at early start and -6.0 SD at latest start of GH therapy.

\section{Molecular studies}

A new point mutation in the Pit-1 gene. The human Pit-1 gene is $17-\mathrm{kb}$ long and composed of six coding exons (24). For each family member analyzed, all six exons of the Pit- 1 gene were amplified by PCR and directly sequenced. Sequence analysis revealed only one alteration, a $\mathrm{T}->\mathrm{C}$ transversion in codon 239 , located in exon 6 . This alteration leads to the substitution of serine for proline at codon 239. The affected children are all homozygous, the unaffected parents all heterozygous for this mutation.

Pro239Ser mutant is unable to transactivate. To analyze the functional effects of the Pro239Ser mutation, we first used site-directed mutagenesis to produce an identical substitution in human Pit-1 cDNA, borne by the expression vector pRSVhPit-1. We shall refer to the parental plasmid as pRSVPit-1WT and to the plasmid bearing the Pro239Ser mutation as pRSVPit-1M. Cotransfection experiments in HeLa cells were performed using one of the Pit-1 expression vectors with a reporter plasmid, $\mathrm{p}(\mathrm{GH} 1) 6 \mathrm{XTKCAT}$, bearing six
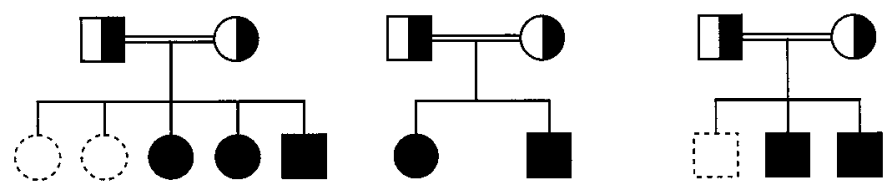

FIG. 1. Pedigrees of the three families with CPHD. Squares, Males; circles, females; solid symbols, individuals who are homozygous for the mutation in the Pit-1 gene; half-solid symbols, persons who are heterozygous at this location; dotted symbols, phenotypically normal individuals who were not examined. 
FIG. 2. Transfection of HeLa cells with vectors expressing either wild-type or Pro239Ser mutant Pit-1. The calcium phosphate precipitation technique was used to transfect the cells. We used $5 \mu \mathrm{g}$ of reporter plasmid and $10 \mu \mathrm{g}$ of expression vector per plate. CAT assays were cell extract per plate, prepared after a 48-h incubation. performed overnight with $25 \mu \mathrm{g}$ total

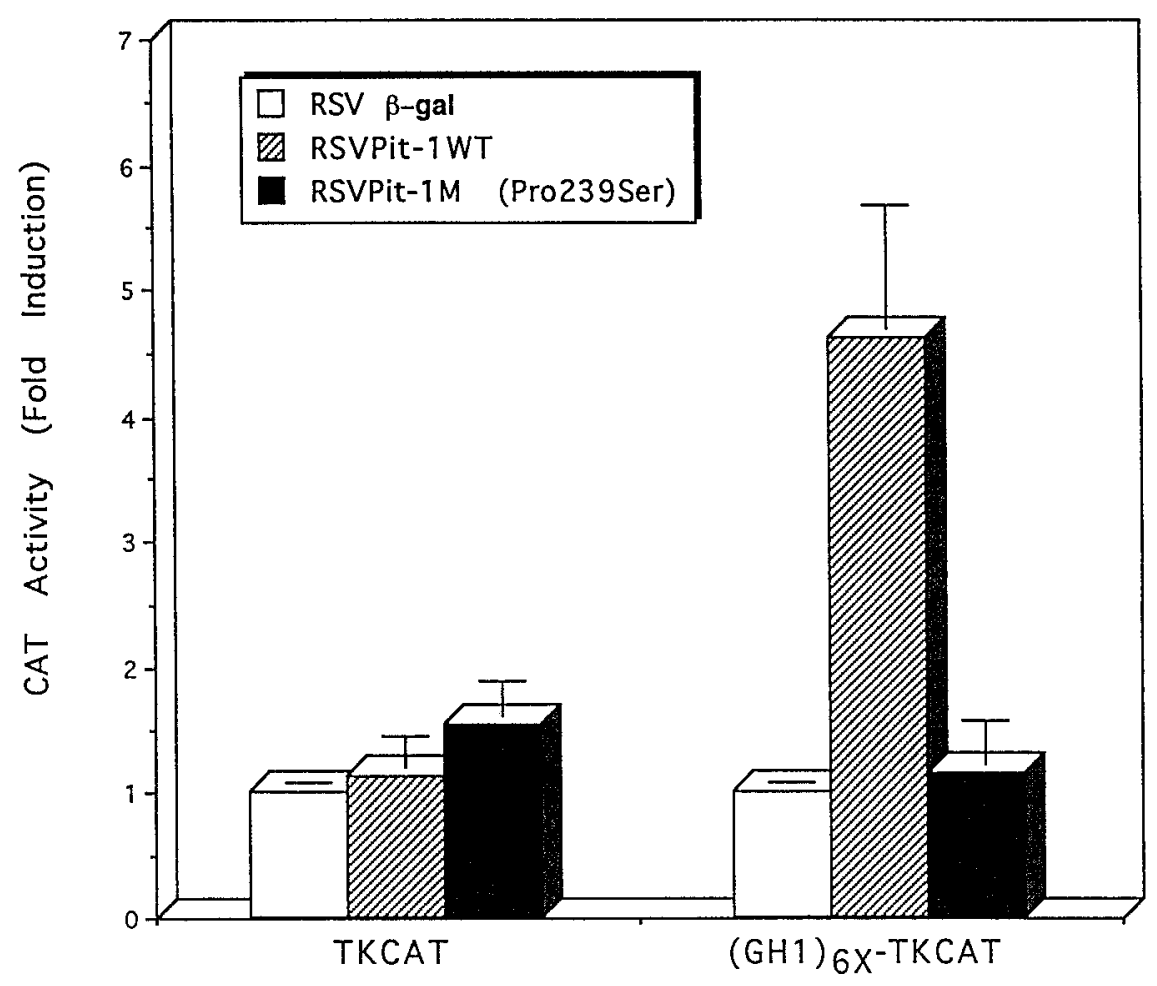

copies of the first Pit-1 binding site of the human GH promoter (hGH1: from -71 to -91 , see Ref. 8), inserted upstream from the TK promoter and the CAT reporter gene. As shown in Fig. 2, the mutant Pit-1 was unable to increase transcription of the (GH1)6XTKCAT fusion-gene construct, whereas wild-type Pit-1 stimulates its transcription 5-fold.

The DNA binding properties of the Pit-1 mutant are unaltered. ${ }^{35}$ S-labeled wild-type and mutant Pit-1 proteins from in vitro transcription/translation reactions were used to test the ability of the Pro239Ser mutant to bind DNA in gel retardation assays. Both proteins are of the correct apparent molecular size (33 or $31 \mathrm{kDa}$, depending on the methionine at which translation is initiated) (data not shown). As shown in Fig. 3, the mutated and wild-type Pit-1 proteins bind with the same affinity to the first Pit-1 DNA-binding site of the human PRL gene (hPRL1P: from -35 to -64 , see Ref. 8). The complexes are specific, because they disappear with an excess of cold hPRL1P oligonucleotide but not with an excess of cold, nonspecific DR4 oligonucleotide. The specificity is further confirmed by the fact that the shifted bands disappear in the presence of anti-Pit-1 antibodies but not in the presence of control serum. A nonspecific lower band is observed with unprogrammed reticulocyte lysate.

Coexpression of the Pro239Ser mutant interferes with the wildtype Pit-1 activity. Because the unaffected parents are all heterozygous for the Pro239Ser mutation, we sought to test the ability of the mutant form to interfere with transactivation of reporter gene expression by wild-type Pit-1. To this end, we cotransfected HeLa cells with the p(GH1)6XTKCAT reporter plasmid and either 14 or $28 \mu \mathrm{g}$ of expression vector, this meaning either pRSV $\beta$ gal alone (control) or equal amounts of two plasmids: pRSV $\beta$ gal and pRSVPit-1WT, pRSV $\beta$ gal

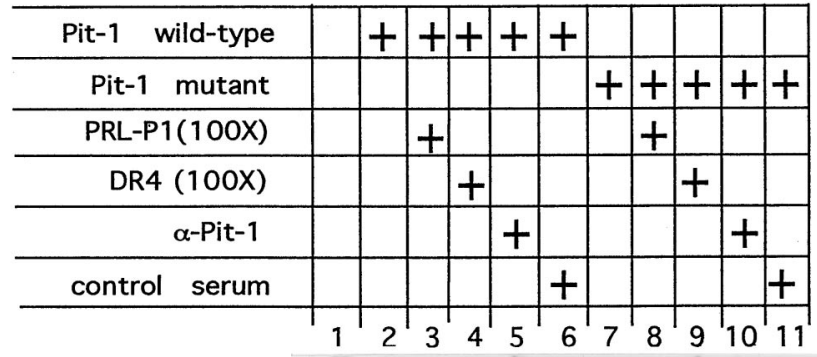

Pit-1 dimerPit-1 monomer-

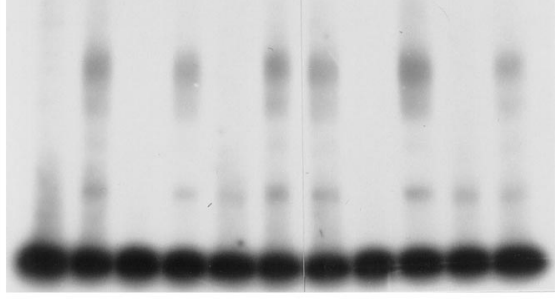

$\mathrm{PRL}-\mathrm{P} 1$ *

FIG. 3. Binding of the wild-type and Pro239Ser mutant Pit-1 proteins to the hPRL1 Pit-1 binding site. Both in vitro translated proteins were tested in gel retardation assays with ${ }^{32} \mathrm{P}$-labeled hPRLP1 oligonucleotide, corresponding to the first Pit- 1 footprint sequence in the proximal human PRL promoter (8).

and pRSVPit-1M, or pRSVPit-1WT and pRSVPit-1M. As shown in Fig. 4, the CAT activity doubles when the amount of pRSVPit-1WT is increased from $7 \mu \mathrm{g}$ to $14 \mu \mathrm{g}$, whether or 


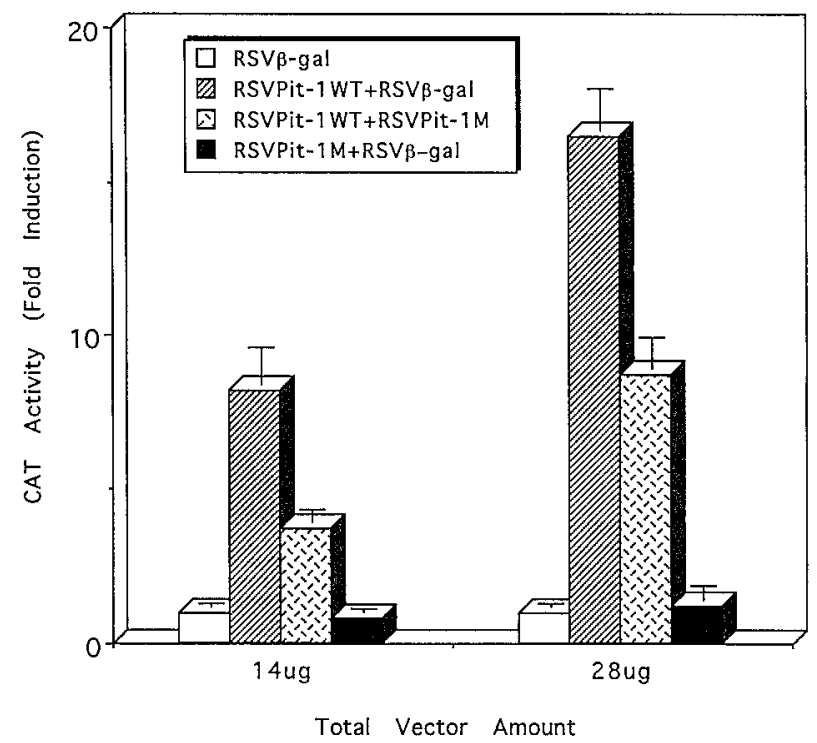

FIG. 4. Transfection of HeLa cells with vectors expressing the wildtype (pRSVPit-1WT) or mutant form of Pit-1 (pRSVPit-1M), introduced alone or simultaneously. In all cases, $5 \mu \mathrm{g}$ (GH1)6XTKCAT reporter plasmid was introduced, in addition to the expression vector(s). The total vector amount indicated on the horizontal axis (14 or $28 \mu \mathrm{g})$ refers to the total amount of pRSV-derived plasmid; when two such plasmids were introduced simultaneously (hatched, grey, and black boxes), each was present in half the indicated amount.

not pRSVPit-1M is also present. We also observe 2-fold lesser transactivation by wild-type Pit-1 at both vector concentrations when the mutated form is expressed. The Pro239Ser form alone is unable to stimulate transcription of the reporter plasmid.

\section{Discussion}

We have analyzed the Pit-1 sequence of three apparently independent families in which hypopituitary children are homozygous and phenotypically normal parents are heterozygous for a Pro239Ser mutation.

Proline 239 is strictly conserved among the Pit- 1 proteins of several species and among other related POU proteins (Fig. 5), implying that it must play an important role in Pit-1 activity. This residue is located at the beginning of the second $\alpha$-helix of the homeodomain, which was originally described as the Pit-1 DNA binding domain (3). In gel retardation experiments, we show that the Pro239Ser mutant form of Pit-1 is still able to recognize the first Pit- 1 binding site of the human PRL proximal promoter and specifically binds to this sequence with about the same affinity as the wild-type Pit-1. These results are in agreement with the three-dimensional conformation of the POU domain [recently established for Oct-1 (25) and for the Pit-1 POU domain (26) cocrystallized with their respective binding sequence], which seems to indicate that residue 239 is not in direct contact with DNA. In addition, Proline 239 occupies the N-cap position of the helix $\alpha 2$ in the Pit- 1 homeodomain. Prolines are frequent at $\mathrm{N}$-cap positions of $\alpha$-helices, where they play a stabilizing role (27). In our mutant, proline 239 is replaced by a serine, another residue known to have a stabilizing effect on $\alpha$-helices when in the N-cap position. Thus, one should not expect the sta-
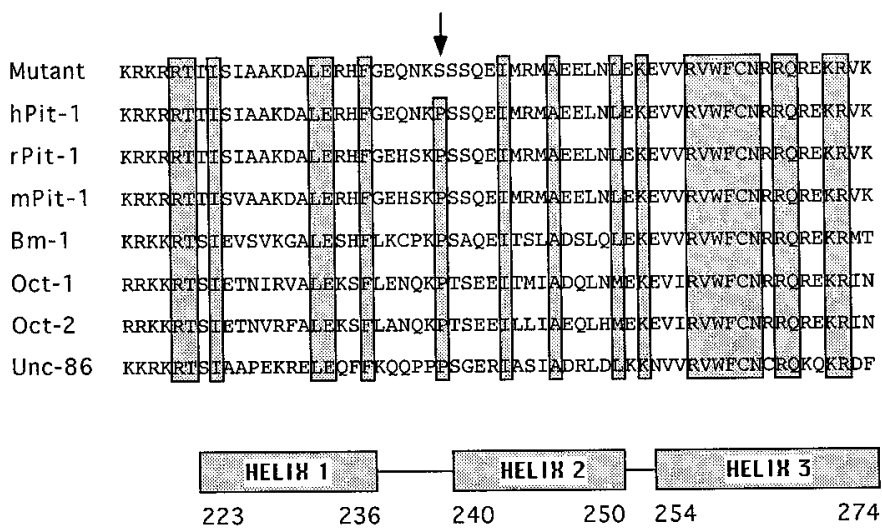

Fig. 5. Alignment of POU protein homeodomains. The species to which each Pit-1 belongs is indicated by an h (human), $\mathrm{r}$ (rat), or $\mathrm{m}$ (mouse). Amino acids that are identical at any position are boxed. The residue mutated in all patients is marked by an arrow. Regions that form $\alpha$-helices, according to the Oct-1 crystallographic structure (21), are also shown by grey boxes.

bility of the second $\alpha$-helix of the Pit-1 homeodomain, and hence the conformation of the protein, to be seriously affected by the Pro239Ser mutation. Furthermore, a genetic screen used to define the important residues for Pit-1 DNAbinding, based on loss of function of fusion proteins between the transactivation domain of GCN4 and chemically mutated Pit-1 DNA binding domains, failed to detect the Pro239Ser mutation described here (28). All these considerations support our finding that this Pit-1 variant is capable of binding DNA with the same affinity as the wild-type form.

The results of our cotransfection experiments (Fig. 2) clearly show that the Pro239Ser mutation causes complete loss of transactivation activity. The hypothesis of nonexpression of the mutated protein in HeLa cells must be rejected, because activation by wild-type Pit-1 is partially inhibited when the vector bearing the mutated cDNA is also present (Fig. 4). Without expression of this cDNA, such an effect would be hard to explain.

When pRSVPit-1WT and pRSVPit-1M are present in equal amount (7 or $14 \mu \mathrm{g}$ each) in cotransfected cells, the transactivation potential of wild-type Pit- 1 is reduced by $50 \%$ (Fig. 4). These in vitro results are in keeping with the clinically observed recessive phenotype of this mutation if we assume that a $50 \%$-reduced level of Pit-1 activity is sufficient to ensure a normal phenotype.

Because Pit- 1 forms dimers on DNA through its POUspecific domain, two mechanisms might account for the ability of the mutant to repress wild type Pit- 1 activity: competition between mutated and wild-type Pit-1 for DNA binding sites; or formation of inactive heterodimers. The first possibility must be rejected because the reporter plasmid was in excess in our experiments [as shown by the 2-fold increase of CAT activity observed when the amount of vector expressing wild-type Pit-1 was doubled, whether this vector was present alone or in combination with the vector expressing the mutated form (Fig. 4)]. We therefore suggest that the observed inhibitory effect of the Pro239Ser protein is caused by formation of heterodimers that can bind to DNA but cannot stimulate transcription, as is the case with mutant homodimers. This model suggests that the mutation of 
Pro239 into a serine abolishes the interaction of Pit-1 with another factor(s) required for transcriptional activation.

In brief, our data show that a single point mutation in codon 239 of the Pit-1 gene, causing the substitution of a serine for a proline, leads to the phenotype of GH, PRL, and TSH deficiency and hypoplasia of the anterior pituitary, when present in both Pit-1 alleles. Because heterozygous individuals are seemingly unaffected, it further seems that a $50 \%$-reduced level of Pit-1 activity is sufficient to ensure a normal phenotype.

The newly recognized, natural, recessive Pit-1 mutation that we describe has been found in only three Middle Eastern families. The relatively frequent and apparently exclusive occurrence of this mutation in a defined geographic region is striking. This occurrence may be based on a so-called founder effect, the three families having a single and common heterozygous ancestor in whom this mutation first arose. Alternatively, we may be in the presence of a hot spot for mutations in the Pit-1 gene within this ethnic community, distinct from the Arg271Trp hot spot that has been described in Caucasians and Mongolians (16).

\section{Acknowledgment}

The authors wish to thank Pierre Lecocq for his technical services in automatic sequencing.

\section{References}

1. Ingraham HA, Albert VR, Chen R, et al. 1990 A family of POU-domain and Pit-1 tissue specific transcriptional activators in pituitary and neuroendocrine development. Annu Rev Physiol. 52:773-791.

2. Bodner M, Castrillo JL, Theill LE, Deerink T, Ellisman M, Karin M. 1988 The pituitary-specific transcription factor GHF-1 is a homeobox-containing protein. Cell. 55:505-518.

3. Ingraham HA, Chen R, Mangalam HJ, et al. 1988 A tissue-specific transcription factor containing a homeodomain specifies a pituitary phenotype. Cell. 55:519-529.

4. Nelson C, Albert VR, Elsholtz HP, Lu LI-W, Rosenfeld MG. 1988 Activation of cell-specific expression of rat growth hormone and prolactin genes by a common transcription factor. Science. 239:1400-1405

5. Fox S, Jong MTC, Casanova J, Ye Z-S, Stanley F, Samuels HH. 1990 The homeodomain protein Pit-1/GHF-1 is capable of binding to and activating cell-specific elements of both growth hormone and prolactin gene promoters. Mol Endocrinol. 4:1069-1080.

6. Steinfelder HJ, Hauser P, Nakayama Y, et al. 1991 Thyrotropin-releasing hormone regulation of the human TSH- $\beta$ expression: role of a pituitary specific transcription factor (Pit-1/GHF-1) and potential interaction with thyroid hormone-inhibitory element. Proc Natl Acad Sci USA. 88:3130-3134.

7. Steinfelder HJ, Radovick S, Wondisford FE. 1992 Hormonal regulation of the thyrotropin-b subunit gene by phosphorylation of the pituitary-specific transcription factor Pit-1. Proc Natl Acad Sci USA. 89:5942-5945.
8. Lemaigre FP, Peers B, Lafontaine DA, et al. 1989 Pituitary-specific factor binding to the human prolactin, growth hormone and placental lactogen genes. DNA. 8:149-159.

9. Rosenfeld MG. 1991 POU-domain transcription factors powerful developmental regulators. Genes Dev. 5:897-907.

10. Theill LE, Castrillo JL, Wu D, Karin M. 1989 Dissection of functional domains of the pituitary-specific transcription factor GHF-1. Nature. 342:945-948.

11. Li S, Crenshaw EB, Rawson EJ, Simmons DM, Swanson LW, Rosenfeld MG. 1990 Dwarf locus mutants lacking three pituitary cell types result from mutations in the POU-domain gene PIT1. Nature. 347:528-533.

12. Tatsumi K, Miyai K, Notomi T, et al. 1992 Cretinism with combined hormone deficiency caused by a mutation in the PIT1 gene. Nat Genet. 1:56-58.

13. Radovick S, Nations M, Du Y, Berg LA, Weintraub BD, Wondisford FE. 1992 A mutation in the POU-homeodomain of Pit-1 responsible for combined pituitary hormone deficiency. Science. 257:1115-1118.

14. Pfaffle RW, DiMattia GE, Parks JS, et al. 1992 Mutation of the POU-specific domain of Pit-1 and hypopituitarism without pituitary hypoplasia. Science. 257:1118-1121.

15. Ohta K, Nobukuni Y, Mitsubuchi H, et al. 1992 Mutations in the Pit-1 gene in children with combined pituitary hormone deficiency. Biochem Biophys Res Commun. 189:851-855.

16. Cohen LE, Wondisford FE, Salvatoni A, et al. 1995 A "hot spot" in the Pit-1 gene responsible for combined pituitary hormone deficiency: clinical and molecular correlates. J Clin Endocrinol Metab. 80:679-684.

17. de Zegher F, Pernasetti F, Vanhole C, Devlieger H, Van den Berghe G, Martial JA. 1995 The prenatal role of thyroid hormone evidenced by fetomaternal Pit-1 deficiency. J Clin Endocrinol Metab. 11:3127-3130.

18. Irie Y, Tatsumi K, Kusuda S, et al. 1995 Screening for Pit-1 abnormality by PCR direct sequencing method. Thyroid. 5:207-211.

19. Okamoto N, Wada Y, Ida S, et al. 1994 Monoallelic expression of norma mRNA in the PIT1 mutation heterozygotes with normal phenotype and biallelic expression in the abnormal phenotype. Hum Mol Genet. 3:1565-1568.

20. Irie Y, Tatsumi K, Ogawa M, et al. 1995 A novel E250X mutation of the Pit-1 gene in patient with combined pituitary hormone deficiency. Endocr J. 42:351-354.

21. Walsh PS, Metzger DA, Higushi R. 1991 Chelex 100 as a medium for simple extraction of DNA for PCR-based typing from forensic material. Biotechniques. 10:506-513.

22. Pernasetti F, Wera S, Belayew A, Martial JA. 1993 Cloning of a human GHF-1/Pit-1 cDNA variant. Nucleic Acids Res. 21:3584.

23. Voz ML, Peers B, Belayew A, Martial JA. 1991 Characterization of an unusual thyroid response unit in the promoter of the human placental lactogen gene. J Biol Chem. 266:13397-13408.

24. Ohta K, Nobukuni Y, Mitsubuchi H, et al. 1992 Characterization of the gene encoding human pituitary-specific transcription factor Pit-1. Gene. 122:387-388

25. Klemm JD, Rould MA, Aurora R, Herr W, Pabo CO. 1994 Crystal structure of the Oct-1 POU domain bound to an octamer site: DNA recognition with tethered DNA binding modules. Cell. 77:21-32.

26. Jacobson EM, Li P, Leon-del-Rio A, Rosenfeld MG, Aggarwal AK. 1997 Structure of Pit-1 POU domain bound to DNA as a dimer: unexpected arrangement and flexibility. Genes Dev. 11:198-212.

27. Richardson JS, Richardson DC. 1988 Amino acid preferences for specific locations at the ends of helices. Science. 240:1648-1652.

28. Liang J, Moey-Rowley S, Maurer RA. 1995 In vivo mutational analysis of the DNA binding domain of the tissue-specific transcription factor Pit-1. J Biol Chem. 270:25520-25525. 